\title{
PENGARUH LEVEL PUPUK ORGANIK CAIR GENETIKA PLUS DAN JARAK TANAM BERBEDA TERHADAP PERTUMBUHAN DAN PRODUKSI BIOMAS RUMPUT GAJAH
} (Pennisetum purpureum)

\author{
Abdul Karim Madina'), Muh. Mukhtar'), Musrifah Nusi ${ }^{3)}$ \\ 1. Alumni of Animal Husbandry department, Faculty of Agriculture, Gorontalo State University \\ 2. Animal Husbandry department, Faculty of Agriculture, Gorontalo State University \\ Email: abdulkarim111adina@gmail.com
}

\begin{abstract}
The purpose of this research was to determine the effect of the level of liquid organic fertilizer (LOF) of Genetika Plus and different spacing on the growth and productionof elephantgrass biomass (Pennisetum purpureum). This research was conducted in Tambo'o Sub-District Tilongkabila, Bone Bolango District, from April to June 2018. The method used in this study is Factorial RAL with two factors. Data were analyzed using analysis of varian. The results showed that under fertilizer treatment and plant spacing had a significantly effect on the growth and production of biomass. The highest plant height was obtained in R3K2 $(397 \mathrm{~cm})$ and the lowest in R0K3 $(210 \mathrm{~cm})$, the highest tillering production was in R3K3 (7.5) and the lowest was in R0K1 (3.5). Whereas biomass production, the highest in fresh matter weight was obtained in R3K1 $(29,076)$ and the lowest in R0K3 $(1,638)$, the highest leaf blade percentage obtained in R3K1 $(38,519)$ and the lowest in R0K1 $(14)$, the highest dry matter weight was obtained in R3K1 (494) and lowest in R0K3 (27.75). Based on the research, the level of genetics plus liquid organic fertilizer (LOF) and plant spacing has a significantly effected on the growth of elephant grass (Pennisetum purpureum) on plant height, fresh matter production, leaf blade percentage, dry matter production and number of tillers.
\end{abstract}

\section{Keywords: Biomass production, elephantgrass, Genetika plus fertilyzer, plant}

\section{PENDAHULUAN}

Hijauan merupakan faktor penting dalam pengembangan ternak ruminansia.Penyediaan hijauan pakan yang cukup dan kualitas nutrisi yang baik merupakan salah satu faktor yang mempengaruhi tingkat produksi seekor ternak.Salah satu hijauan yang biasa diberikan pada ternak ruminansia adalah rumput gajah (Pennisetum purpureum) yang dapat digunakan untuk menunjang keberhasilan dalam meningkatkan produktivitas ternak ruminansia. Ketersediaan hijauan yang kontinyu dan berkualitas sangat dibutuhkan dalam pengembangan usaha peternakan.Namun demikian ketersediaan lahan yang digunakan untuk menanam hijauan semakin terbatas, sehingga system budidaya intensif sangat dipelukan dalam mem produksi biomas atau hijauan yang tinggi dan tersedia secara berkelanjutan.salah satu hijauan yang respon baik adalah rumput gajah (pennisetum purpureum).

Rumput gajah merupakan jenis rumput unggul yang mempunyai produktivitas dan kandungan zat gizi yang cukup tinggi. Untuk memenuhi ketersediaan rumput gajah yang berkualitas baik maka dilakukan budidaya. Budi daya rumput gajah pada lahan yang subur akan menghasilkan produktivitas yang lebih baik, terlebih jika dilakuhkan pemupukan. Rumput gajah diketahui sangat respon terhadap pemupukan pupuk organik maupun pupuk anorganik masingmasing dapat diberikan dalam bentuk 
padat maupun cair. Selain respon terhadap pumupukan, dalam budidaya rumput gajah jarak tanam juga sangat menetukan produksi biomas atau produksi bahan kering. Beberapa yang menentukan pertumbuhan hijauan makanan ternak adalah penganturan jarak tanam dan pemupukan.dua faktor ini memberikan pengaruh positif dalam pertumbuhan dan produksi biomas HMT. Jarak tanam HMT akan menetuhkan prduksi biomas dan keberlanjutan pertumbuhan tanamam dalam jangka panjang. Rumput gajah selain harus diatur jarak tanam yang cocok, juga memilik respon yang baik terhadap pupuk organik terutama pupuk organik cair

Sekarang ini telah banyak diproduksi secara pabrik pupuk organik cair dan memiliki dosis tersendiri dalam aplikasinya pada tanaman, yang menjadi masalah adalah para peternak tidak mampuh melihat puppuk organik cair yang cocok bagi tanman hijauan makan ternak mereka,salah satu pupuk organik cair yang terbaru dibuat adalah pupuk organik cair genetika plus.

\section{METODE PENELITIAN}

Penelitian ini dilaksanakan pada bulan April - Juni 2018 di pada lahan pastura di Desa Tamboo, Kecamatan Tilong Kabila, Kabupaten Bone Bolango. Lokasi ini dipilih karena lahan ini dipakai sebagai tempat penanaman jagung yang berati lahan ini subur.

Penelitian ini menggunakan Rancangan Acak Lengkap (RAL) pola Factorial dengan dua faktor..

Faktor pertama adalah level pupuk organik cair genetika plus (POC-GP).

$\mathrm{R} 0=$ Kontrol

$\mathrm{R} 1=200 \mathrm{ml}$ POC-GP

$\mathrm{R} 2=300 \mathrm{ml}$ POC-GP

$\mathrm{R} 3=400 \mathrm{ml}$ POC-GP

Faktor kedua adalah jarak tanam. $\mathrm{K} 1=25 \mathrm{~cm} \times 25 \mathrm{~cm}\left(16\right.$ tanaman $\left./ \mathrm{m}^{2}\right)$
$\mathrm{K} 2=25 \mathrm{~cm} \times 50 \mathrm{~cm}\left(8\right.$ tanaman $\left./ \mathrm{m}^{2}\right)$

$\mathrm{K} 3=50 \mathrm{~cm} \times 50 \mathrm{~cm}\left(4\right.$ tanaman $\left./ \mathrm{m}^{2}\right)$

Data yang telah ditabulasi selajutnya dianalisis dengan analisis of varian (ANOVA), jika terdapat berpengruh nyata dilanjukan dengan uji beda nyata terkecil (BNT)

Parameter pengamatan meliputi:

a. Tinggi tanaman diukur dengan menggunakan meter, pengukuran dilakukan dari permukaan tanah sampai titik tumbuh teratas dan diamati dua minggu sekali.

b. Produksi anakan dilakukan dengan minghitung jumlah tiap anakan setiap satuan perlakuan.

c. Produksi biomas (bahan segar) dihitung degan cara menimbang tanaman setelah panen.

d. Persentase daun dihitung dengan menggunakan rumus sebagai berikut:

$$
\% \text { Daun }=\frac{\text { Jumlah PB }}{\text { Jumlah PBS }}^{\text {Jumlon }}
$$

e. Produksi bahan kering

Perhitungan bahan kering menggunakan analisis kadar air berdasarkan Sebagai berikut

$$
\begin{aligned}
& \text { Bahan } \text { kering }=\frac{\mathrm{x}+\mathrm{y}-\mathrm{z}}{\mathrm{y}} \times 100 \% \\
& \text { Di mana: } \quad \mathrm{X}=\text { Berat wodes } \\
& \mathrm{Y}=\text { Berat sampel sebelum oven } \\
& \mathrm{Z}=\text { Berat sampel setelah oven } \\
& \text { Bahan Kering }=100 \%-\mathrm{KA}
\end{aligned}
$$

\section{HASIL PEMBAHASAN}

\section{Pertumbuhan Rumput Gajah}

Dari hasil analisis sidik ragam yang ditunjukan pada Lampiran 1 dan 2 pertumbuhan rumput gajah (Pennisetum purpureum) pada perlakuan antara pupuk organik cair dan jarak tanam berpengaruh sangat nyata $(\mathrm{P}<0,01) \quad$ terhadap pertumbuhan tinggi tanaman dan jumlah anakan sedangan interaksi antara pupuk 
organik cair genetika plus dan jarak tanam tidak ada interaksi terhadap tinggi tanaman dan anakan.

Rata-rata pertumbuhan rumput gajah pada tiap perlakuan disajikan pada Tabel 2.

Tabel 1. Data produksi rumput gajah

\begin{tabular}{ccccc}
\hline \multirow{2}{*}{ Variabel } & \multicolumn{4}{c}{ Perlakuan } \\
\cline { 2 - 5 } & R0 & R1 & R2 & R3 \\
\hline Tinggi tanaman & & & & \\
\hline K1 & $343^{\mathrm{a}}$ & $374^{\mathrm{a}}$ & $378^{\mathrm{a}}$ & $393^{\mathrm{b}}$ \\
K2 & $250^{\mathrm{a}}$ & $341^{\mathrm{b}}$ & $390^{\mathrm{c}}$ & $397^{\mathrm{c}}$ \\
K3 & $210^{\mathrm{a}}$ & $327^{\mathrm{b}}$ & $374^{\mathrm{c}}$ & $377^{\mathrm{c}}$ \\
\hline Jumlah anakan & & & & \\
\hline K1 & $3.50^{\mathrm{a}}$ & $4.75^{\mathrm{a}}$ & $5.50^{\mathrm{a}}$ & $6.50^{\mathrm{b}}$ \\
K2 & $4.00^{\mathrm{a}}$ & $5.00^{\mathrm{a}}$ & $6.25^{\mathrm{a}}$ & $6.75^{\mathrm{b}}$ \\
K3 & $4.50^{\mathrm{a}}$ & $5.00^{\mathrm{a}}$ & $6.00^{\mathrm{a}}$ & $7.50^{\mathrm{b}}$ \\
\hline
\end{tabular}

Keterangan : Perbedaan pada baris yang sama menunjukan pengaruh sangat nyata $(\mathrm{P}<0.01)$

K1 : Jarak tanam $25 \mathrm{~cm} \times 25 \mathrm{~cm}$

$\mathrm{K} 2$ : Jarak tanam $25 \mathrm{~cm} \times 50 \mathrm{~cm}$

$\mathrm{K} 3$ : Jarak tanam $50 \mathrm{~cm} \times 50 \mathrm{~cm}$

R0 : Kontrol

R1 : $200 \mathrm{ml}$

$\mathrm{R} 2 \quad: 300 \mathrm{ml}$

R3 : $400 \mathrm{ml}$

\section{Tinggi Tanaman}

Berdasaran Tabel 1 menunjukkan bahwa penggunaan pupuk organik cair dengan level dan jarak tanam yang berbeda menunjukkan rataan tinggi tanaman rumput gajah selama penelitian pada setiap perlakuan berpengaruh sangat nyata terhadap tinggi tanaman. Hasil rataan tertinggi terdapat pada perlakuan R3K2 yaitu dengan tinggi $(397 \mathrm{~cm})$ dan rataan terendah pada R0K3 yaitu dengan tinggi $(210 \mathrm{~cm})$. Hal ini disebabkan oleh penggunaan pupuk organik genetika plus yang mampu memperbaiki kultur tanah sehingga tanaman mampu menyerap unsur hara degan baik. Hal ini sesuai degan pernyataan Kusuma (2014) bahwa pupuk merupakan sumber unsur hara penting bagi tanaman dalam proses pertumbuhan baik dalam meningkatkan tinggi vertikal, jumlah daun, maupun jumlah anakan serta produksi tanaman.

Setiawan (2005) menyatakan bahwa unsur nitrogen $(\mathrm{N})$ berfungsi untuk merangsang pertumbuhan tanaman secara keseluruhan, terutama batang tanaman.Unsur phospor $(\mathrm{P})$ bagi tanaman lebih banyak berfungsi untuk merangsang pertumbuhan akar, khususnya akar tanaman muda.Unsur kalium $(\mathrm{K})$ berperan dalam membentuk protein dan karbohidrat bagi tanaman.Menurut Muhakka dkk (2014) unsur nitrogen dibutuhkan dalam proses pembentukan protein tanaman sehingga meningkatkan pertumbuhan vegetatif tanaman seperti batang, daun dan akar.

\section{Produksi Anakan}

Hasil penelitian menunjukkan pemberian dosis pupuk organik cair degan level dan jarak tanam yang berbeda memberikan pengaruh yang nyata terhadap jumlah anakan. Hasil rataan tertinggi jumlah anakan yang tertinggi terdapat pada R3K3 yaitu dengan 7.5tunas dan rataan terendah pada R0K1 yaitu 3.5tunas tanaman rumput gajah (Pennisetum purpureum).

Pemberian jarak tanam mempengaruhi tinggi rendahnya hasil tanaman, sehingga tinggi rendahnya hasil tanaman mempengaruhi produksi dalam satu areal. Peningkatan produksi diawali oleh meningkatnya hasil per satuan luas, kemudian setelah titik maksimum tercapai hasil dapat menurun. Jarak tanam mempengaruhi ketersediaan unsur hara dan air bagi tanaman yang berperan dalam proses pertumbuhan dan perkembangan tanaman. Hal ini sesuai dengan pernyataan Khakim dan Muhammad (2017) bahwa pada tumbuhan dengan jarak tanam yang lebih lebar memungkinkan pembentukan 
anakan lebih banyak dibandingkan dengan jarak tanam yang lebih sempit karena tingkat kompetisi hara dan air lebih kecil.

\section{Produksi Biomas}

Dari hasil analisis sidik ragam yang ditunjukan pada Lampiran 3, 4 dan 5 produksi biomas rumput gajah (Pennisetum purpureum) pada perlakuan antara pupuk dan jarak tanam berpengaruh sangat nyata $(\mathrm{P}<0,01)$ terhadap produksi biomas tanaman, pada perlakuan antar interaksi terhadap produksi bahan segar dan persentase daun memiliki interaksi sedangkan produksi bahan kering tidak interaksi. Rata-rata hasil produksi biomas rumput gajah pada tiap perlakuan disajikan pada Tabel 3.

Tabel 2. Data produksi bahan segar (PBS), persentase daun (PD) dan produksi bahan kering (PBK).

\begin{tabular}{|c|c|c|c|c|}
\hline \multirow[t]{2}{*}{ Variable } & \multicolumn{4}{|c|}{ Perlakuan } \\
\hline & R0 & R1 & $\mathrm{R} 2$ & R3 \\
\hline \multicolumn{5}{|l|}{$\operatorname{PBS}\left(\mathrm{gr} / \mathrm{m}^{2}\right)$} \\
\hline K1 & $13,20^{a}$ & $20,99 a$ & $26,38^{b}$ & $29,08^{b}$ \\
\hline K2 & 4,93 a & $10,30^{\mathrm{a}}$ & $17,80^{\mathrm{b}}$ & $18,41^{\mathrm{b}}$ \\
\hline K3 & $1,64^{\text {a }}$ & $8,29^{a}$ & 11,23 a & $12,78^{b}$ \\
\hline \multicolumn{5}{|l|}{$\mathrm{PD}\left(\mathrm{gr} / \mathrm{m}^{2}\right)$} \\
\hline K1 & $324.40^{a}$ & $538.59^{b}$ & $583.72^{b}$ & $616.31^{c}$ \\
\hline K2 & $256.28^{a}$ & $283.88^{a}$ & $288.11^{a}$ & $295.88^{a}$ \\
\hline $\mathrm{K} 3$ & $126.97^{a}$ & $141.85^{a}$ & $143.56^{a}$ & $145.09^{a}$ \\
\hline \multicolumn{5}{|l|}{$\mathrm{PBK}\left(\mathrm{gr} / \mathrm{m}^{2}\right)$} \\
\hline K1 & $224.00^{a}$ & $303.75^{a}$ & $448.50^{\mathrm{b}}$ & $494.00^{b}$ \\
\hline K2 & $84.00^{a}$ & $175.00^{a}$ & $302.25^{b}$ & $313.00^{\mathrm{b}}$ \\
\hline K3 & $27.75^{\mathrm{a}}$ & $141.75^{a}$ & $189.50^{\mathrm{a}}$ & $217.50^{\mathrm{b}}$ \\
\hline
\end{tabular}

Keterangan : Perbedaan pada baris yang sama menunjukan pengaruh sangat nyata $(\mathrm{P}<0.01)$

K1 : Jarak tanam $25 \mathrm{~cm} \times 25 \mathrm{~cm}$

K2 : Jarak tanam $25 \mathrm{~cm} \times 50 \mathrm{~cm}$

K3 : Jarak tanam $50 \mathrm{~cm} \times 50 \mathrm{~cm}$

R0 : Kontrol

R1 : $200 \mathrm{ml}$

R2 : $300 \mathrm{ml}$

$\mathrm{R} 3 \quad$ : $400 \mathrm{ml}$

\section{Produksi bahan segar}

Dari hasil penelitian menunjukkan bahwa pemberian level pupuk organik cair dan jarak tanam yang berbeda pada perlakuan memberikan pengaruh sangat nyata terhadap produksi bahan segar rumput gajah (Pennisetum purpureum) menunjukkan bahwa rataan berat segar yang paling banyak adalah berat segar pada perlakuan R3K1 dengan berat (29.08), sedangkan rataan yang paling rendah adalah berat segar pada perlakuan R0K3 dengan berat (1.64).

Hal ini diduga selain pemberian pupuk organik cair genetika plus dan jarak tanam juga disebabkan faktor lingkungan yang lembab dan terbuka serta keadaan tanah yang baik sehingga menyebabakan produksi bahan segar miningkat. Hal ini didukung pendapat Sawen (2012) faktor yang dibutuhkan dalam pertumbuhan adalah suplai air, cahaya dan hara.Cahaya matahari merupakan faktor iklim yang sangat penting dalam fotosintesis karena berperan sebagai sumber energi pembentuk tanaman.Sedangkan pernyataan Sari (2012) menyatakan produksi rumput dipengaruhi pertambahan tinggi dan jumlah anakan yang dihasilkan.

\section{Persentase Daun}

Seperti disajikkan pada Tabel 2 berdasarkan hasil analisis persentase daun hasil tertinggi pada perlakuan R3K1 $(616.308 \%)$ sedangkan rataan yang terendah jarak tanam R0K3 (126.963\%).Hal ini diduga disebabkan karena jarak tanam yang lebih padat sehingga penguapan air lambat.Ketersedian kebutuhan air pada tanaman rumput gajah sangat penting untuk proses fotosintesis sehingga menyebabkan pertumbuhan dan produktivitas meningkat. Ifradi et al. (2003) menyatakan bahwa semakin tinggi kadar air tanah maka unsur dan transportasi unsur hara maupun air lebih baik, sehingga laju fotosintesis untuk dapat menghasilkan cadangan makanan bagi 
pertumbuhan tanaman lebih terjamin dan produksi pun akan meningkat. Sutejo (2002) menyatakan bahwa nitrogen sangat diperlukan untuk merangsang pertumbuhan vegetatif, memperbesar ukuran daun dan meningkatkan kandungan klorofil tanaman.

\section{Produksi bahan kering}

Hasil rataan produksi bahan kering rumput gajah (Pennisetum purpureum) dapat dilihat pada tabel 3 menunjukkan bahwa pemberian pupuk organik cair genetika plus dan jarak tanam tertinggi pada R3K1(494.00 gram) dan data yang terendah pada perlakuan R0K3 yaitu (27.75 gram). Hal ini diduga karena pupuk genetika plus mengandung unsur hara nitrogen.Pemberian pupuk yang mengadung nitrogen menyebabkan produksi bahan kering yang lebih banyak, dimana semakin tinggi dosis pemupukan $\mathrm{N}$, maka penggunaan nitrogen semakin tinggi, sehingga mensuplai produksi berat kering rumput meningkat. Hal ini sesuai dengan pendapat Aryanto dan Polakitan (2009), mengatakan bahwa besarnya persentasi pertumbuhan tergantung ketersediaan unsur hara di dalam tanah khususnya nitrogen dimana unsur $\mathrm{N}$ dapat meningkatkan respirasi untuk merangsang serapan unsur hara sehingga meningkatkan pertumbuhan dan produksi tanaman

\section{KESIMPULAN}

Penggunaan level pupuk organik cair (POC) genetika plus dan jarak tanam memberikan pengaruh nyata pada pertumbuhan rumput gajah (Pennisetum purpureum) terhadap tinggi tanaman, produksi segar, produksi daun, produksi bahan kering dan jumlah anakan.

\section{DATAR PUSTAKA}

Aryanto dan D. Polakitan. 2009. Uji produksi rumput dwarf (Pennisetum purpureum CV. Dwarf). Jurnal
Ilmiah, Balai Pengkajian Teknologi Pertanian Sulawesi Utara, JL. Kampus Pertanian Kalasey

Khakim dan Muhammad. 2017. Pengaruh Umur Bibit Dan Jarak Tanam Terhadap Pertumbuhan Dan Hasil Tanaman Padi (Oryza sativa L) Dengan Pola Tanam Sri (System Of Rice Intensification). Jurnal Agroteknologi Merdeka Pasuruan 1(1) : 1-9.

Ifradi, M. Peto, Elsifitriana. 2003. Pengaruh pemberian pupuk kandang dan mulsa jerami padi terhadap produksi dan nilai gizi rumput raja (Pennisetum purpuphoides) pada tanah Podzolik Merah Kuning. J. Peternakan dan Lingkungan. 10: 31 - 40.

Kusuma, M.E. 2014. Respon Rumput Gajah(Pennisetum purpureum) TerhadapPemberian Pupuk Majemuk. Fakultas Peternakan Universitas Kristen Palangka Raya.

Mufarihin, A., D.R. Lukiwati dan Sutarno. 2012. Pertumbuhan dan Bobot Bahan Kering Rumput Gajah dan Rumput Raja pada Perlakuan Aras Auksin yang Berbeda. Animal Agriculture Journal, Vol. 1 No. 2, 2012, P1-15.

Muhakka, A. Napoleon dan P. Rosa. 2012. Pengaruh pemberian pupuk cair terhadap produksi rumput Gajah Taiwan (pennisetum purpureum schumach)

Sari, Rica Mega. 2012. Produksi Dan Nilai Nutrisi Rumput Gajah (Pennisetum Purpureum) cv. Taiwan Yang Diberi Dosis Pupuk N,P,K Berbeda Dan CMA Pada Lahan Kritis Tambang 
Batubara. Padang : Universitas Andalas.

Sawen, Diana. 2012. Pertumbuhan Rumput Gajah (Pennisetum purpureum) Dan Benggala (Panicum maxicum) Akibat Perbedaan Intensitas Cahaya. Universitas Papua : Manokwari.

Setiawan IS. 2005. Memanfaatkan Kotoran Ternak. Jakarta: Penebar Swadaya.

Sutedjo dan Kartosapoetra. 2002. Pengantar Ilmu Tanah, Terbentuknya Tanah dan Tanah Pertanian. Penerbit Rineka. Jakarta. 